\title{
Persepsi Siswa SMA Selama Pembelajaran Daring Saat Pandemi Covid-19
}

\author{
Anastasia Br Sembiring, Roswita Oktavianti \\ anastasyabunga2020@gmail.com,roswitao@fikom.untar.ac.id
}

Fakultas Ilmu Komunikasi Universitas Tarumanagara

\begin{abstract}
The Coronavirus Disease (Covid-19) pandemic has a huge impact in every aspects of people's lives. One of the aspects is education. The Government enforces online distance learning rules for all schools to prevent the spread of Coronavirus. This research is about the issue of high school students' perception about online learning during the Covid-19 Pandemic. This research uses qualitative research with a case study method. The techniques used for data collection is interview. The subjects of this research are students of SMA Santa Maria Medan based on their grade level. In this research, the researcher conduct an interview. The results showed that students of SMA Santa Maria Medan experienced difficulties during online learning. The difficulties faced is that high school students are required to independently understand the lessons that have been explained by the teacher, besides that unstable network is also considered as one of the factors that creates misunderstanding (miss communication) of the meaning received by students. Students also find it so hard to interact with other students during online learning and students are not feeling motivated because the teacher learning system only provides material and assignments that absolutely makes students tired and bored of learning
\end{abstract}

Keywords: coronavirus disease pandemic, online learning, perception

\begin{abstract}
Abstrak
Pandemi Coronavirus Disease (Covid-19) menyebabkan dampak yang begitu besar bagi seluruh aspek kehidupan masyarakat salah satunya pendidikan. Pemerintah menerapkan aturan pembelajaran jarak jauh secara dalam jaringan (daring) pada seluruh sekolah untuk mencegah penyebaran virus corona. Pembelajaran daring ini membentuk persepsi yang berbeda bagi setiap peserta didik. Persepsi adalah kemampuan otak dalam menerjemahkan stimulus atau proses untuk menerjemahkan stimulus yang masuk ke dalam alat indera manusia. Penelitian ini mengangkat persoalan mengenai persepsi siswa SMA selama pembelajaran daring saat pandemi Covid-19. Penelitian ini menggunakan pendekatan kualitatif dengan metode studi kasus. Studi kasus penelitian ini dilaksanakan di SMA Santa Maria Medan. Pengumpulan data menggunakan teknik wawancara. Subyek penelitian adalah siswa SMA Santa Maria Medan. Objek penelitian adalah persepsi siswa SMA selama pembelajaran daring saat pandemi Covid-19. Wawancara dilaksanakan melalui konferensi video. Hasil penelitian menunjukkan bahwa persepsi siswa SMA selama pembelajaran daring saat Pandemi Covid-19 adalah bahwa pembelajaran daring yang dilaksanakan selama pandemi tidak efektif. Siswa SMA dituntut untuk mandiri memahami pelajaran yang telah dijelaskan oleh guru. Selain itu, masalah jaringan menjadi faktor utama dalam kesalahpahaman makna yang diterima oleh siswa. Siswa juga jarang berinteraksi dengan siswa lainnya selama pembelajaran daring. Siswa merasa tidak memiliki motivasi karena sistem pembelajaran di mana guru hanya memberikan materi dan tugas yang membuat siswa jenuh.
\end{abstract}

Kata Kunci: pandemi covid-19, pembelajaran daring, persepsi 
Anastasia Br Sembiring, Roswita Oktavianti: Persepsi Siswa SMA Selama Pembelajaran Daring Saat Pandemi Covid-19

\section{Pendahuluan}

Pandemi Coronavirus Disease (Covid-19) menyebabkan dampak yang begitu besar bagi seluruh aspek kehidupan masyarakat. Salah satu aspek tersebut adalah pendidikan. Hingga saat ini, berbagai institusi pendidikan masih memberlakukan pembelajaran dalam jaringan (daring). Surat Edaran dari Kementerian Pendidikan dan Kebudayaan (Kemendikbud) menginstruksikan untuk memberlakukan pembelajaran secara daring dari rumah bagi siswa dan mahasiswa; pegawai, guru, dosen melakukan aktivitas bekerja, mengajar atau memberi kuliah dari rumah melalui video conference, digital documents dan sarana daring lainnya (Kemendikbud, 2020).

Pembelajaran daring ini membentuk persepsi yang berbeda bagi peserta didik. Persepsi merupakan proses komunikasi dasar di mana seseorang menciptakan makna ketika berkomunikasi dengan diri sendiri dan berkomunikasi dengan orang lain (Wood, 2011). Persepsi merupakan inti dari komunikasi, jika persepsi tidak akurat, akan sulit berkomunikasi dengan efektif. Persepsi meliputi penginderaan (sensasi) melalui alat-alat indera (indera peraba, indera penglihat, indera pencium, indera pengecap, dan indera pendengar), atensi, dan interpretasi (Mulyana, 2020). Pembelajaran secara daring menuntut siswa bertanggung jawab, memotivasi diri, dan dapat melakukan komunikasi dengan guru dan siswa lainnya melalui teknologi informasi dan komunikasi.

Kasus penularan Covid-19 di Sumatera Utara mencapai 9.468 orang pada Senin, 21 September 2020. Kasus tersebut terjadi di enam wilayah dengan akumulasi terbanyak penderita konfirmasi positif terjadi di Kota Medan dengan 5.407 kasus (CNN Indonesia, 2020). Hal tersebut menyebabkan seluruh institusi pendidikan melakukan pembelajaran secara daring. Salah satu institusi pendidikan tersebut adalah SMA Santa Maria Medan. Selama pembelajaran daring, guru melakukan berbagai strategi dalam memberikan tugas kepada siswa. Salah satu tugas yang diberikan oleh guru adalah membuat rangkuman yang telah dipelajari selama pembelajaran daring melalui media Tiktok.

Kelemahan utama pembelajaran daring, yaitu minimnya intensitas pertemuan antar siswa dan pengajar (Wardana, Toenlioe, Wedi, 2018). Proses pembelajaran daring sangat berbeda dengan pembelajaran secara tatap muka. Selama pembelajaran daring, pengajar sering memberikan tugas kepada siswa yang dapat menyebabkan kejenuhan bagi siswa. Selain itu, siswa dituntut untuk kreatif dan melek teknologi karena tugas yang diberikan bersifat digital. Perubahan proses pembelajaran ini membentuk persepsi yang berbeda antar siswa SMA Santa Maria Medan. Oleh sebab itu penulis tertarik untuk melakukan penelitian mengenai persepsi siswa SMA selama pembelajaran daring saat Pandemi Covid-19. Penelitian ini bertujuan untuk mengetahui persepsi siswa SMA selama pembelajaran daring saat Pandemi Covid19. Dengan mengetahui jawaban dari masalah yang ingin diteliti maka penelitian ini dapat membantu pihak-pihak yang bersangkutan seperti guru dan siswa.

\section{Metode Penelitian}

Pendekatan yang digunakan dalam penelitian ini adalah pendekatan kualitatif yaitu meneliti persepsi siswa SMA saat pembelajaran daring saat Pandemi Covid-19. Penelitian ini menggunakan metode studi kasus. Studi kasus dilakukan pada SMA Santa Maria Medan tahun ajaran 2020/2021. Subyek penelitian ini adalah siswa 
SMA Santa Maria Medan. Obyek penelitian ini pengamatan peneliti terhadap aktivitas (activity) individu-individu (actors) yang ada pada tempat (place) tertentu (Sugiyono, 2015). Berdasarkan pemahaman obyek menurut para ahli tersebut, obyek penelitian ini mengamati situasi pembelajaran daring khususnya persepsi siswa SMA selama pembelajaran berlangsung.

Wawancara tidak terstruktur dan studi kepustakaan merupakan metode pengumpulan data yang dilakukan dalam penelitian ini. Esterberg (2002) mendefinisikan wawancara adalah pertemuan dua orang untuk bertukar informasi dan ide melalui tanya jawab, dapat dikonstruksikan makna dalam suatu topik tertentu (Sugiyono, 2015). Dalam wawancara tidak terstruktur, peneliti belum mengetahui secara pasti data yang diperoleh, sehingga peneliti lebih banyak mendengarkan cerita informan. Wawancara dengan narasumber dilaksanakan melalui konferensi video Zoom dikarenakan situsi dan kondisi Pandemi Covid-19 yang tidak memungkinkan untuk bertemu secara langsung. Narasumber dalam penelitian ini yaitu Firdaus Saragih yang merupakan siswa kelas X IPS, Amanda Togatorop merupakan siswa kelas XI IPS, dan Aminda Tioni Sihombing yang merupakan siswa kelas XII IPS.

\section{Hasil Temuan dan Diskusi}

Peneliti menemukan bahwa tahapan proses persepsi siswa dalam pembelajaran daring adalah sebagai berikut.

\section{Terjadinya Stimulasi Alat Indera (Sensory Stimulation)}

Siswa dalam melaksanakan pembelajaran daring mendapatkan berbagai makna yang diperoleh. Siswa menangkap pelajaran karena cara penyampaian guru yang mudah dimengerti oleh siswa. Lalu, siswa tidak akan menangkap penjelasan guru ketika penjelasan tersebut tidak bermakna bagi siswa. Guru akan mengingatkan kembali materi pelajaran yang sering dilupakan oleh siswa dan pada saat itu juga siswa menyadari bahwa terdapat materi yang selama ini tidak bermakna bagi siswa tersebut. Menurut DeVito (2008) individu akan menangkap apa yang bermakna bagi individu dan tidak menangkap yang kelihatannya tidak bermakna. Hal ini diungkapkan oleh Aminda sebagai narasumber dalam penelitian ini.

"Ada tentang pedesaan pelajarannya Pak Dimpu. Cara penyampaiannya bapak itu karena guru muda lebih gampang diingat kak daripada guru yang sudah lansia. Kalau di luar pelajaran pastinya tugas sih. Kadang aku lupa tiba-tiba, langsung ingat ketika gurunya itu suka dadakan nge-chat nanyain sudah ngumpulin tugas atau belum. Tiba-tiba guru nongol aja di grup nanyain pengumpulan tugas, jadinya saya langsung buru-buru ngerjain. Kadang juga guru itu mau nanya tugas yang sudah lama dan kami pun juga suka lupa kan.” (Aminda)

\section{Stimulasi Terhadap Alat Indra Diatur}

Menurut DeVito (2011:80) pada tahap kedua, rangsangan terhadap alat indra diatur menurut berbagai prinsip. Salah satu prinsip yang digunakan adalah prinsip proksimitas (proximity), atau kemiripan. Demikian pula individu mempersepsikan pesan yang datang segera setelah pesan yang lain sebagai satu unit dan menganggap bahwa keduanya tentu saling berkaitan. Menurut narasumber 1, Firdaus, alasan sekolah diliburkan untuk memutuskan rantai virus. Namun, narasumber berubah pikiran mengatakan bahwa Covid-19 dengan pembelajaran daring tidak 
berhubungan. Narasumber 1 menyatakan jika kedua hal tersebut berhubungan maka seharusnya mal dan tempat hiburan pun ditutup untuk memutuskan rantai virus.

"Ada hubungan dan tidak ada hubungan. Kalau ada hubungannya, alasan kita libur itu karena adanya Covid-19 supaya memutus rantai virus kan. Tapi kalau tidak ada hubungan Covid-19 dengan pembelajaran daring adalah kenapa sekolah ditutup dan belajar melalui daring? sedangkan semua mal mulai dibuka. Pertama aja sih aku bilangnya kalau Covid-19 dengan pembelajaran daring itu ada hubungannya. Tetapi lama kelamaan mengikuti proses belajar mengajar, saya gak yakin ini ada hubungannya karena mal dibuka tetapi sekolah belum bisa dibuka." (Firdaus Saragih)

Prinsip yang lain adalah kelengkapan (closure). Individu memandang atau mempersepsikan suatu gambar atau pesan yang dalam kenyataan tidak lengkap sebagai gambar atau pesan yang lengkap (DeVito, 2011). Dalam penelitian ini sangat berkaitan dengan prinsip closure. Siswa mengalami miscommunication atau kesalahpahaman saat berlangsungnya pembelajaran daring. Hal tersebut disebabkan oleh jaringan atau sinyal yang dimiliki oleh siswa. Materi pelajaran yang telah dijelaskan oleh guru akan membentuk persepsi yang berbeda-beda bagi siswa ketika jaringan tersebut tidak bagus.

Materi tersebut bisa terdengar ambigu bagi siswa sehingga siswa harus belajar mandiri untuk mengerti dan memahami penjelasan guru tersebut. Menurut DeVito (2011:81), individu mendengar dengan bagian-bagian yang tampaknya logis untuk melengkapi pesan tersebut. Hal ini merupakan kutipan narasumber mengenai kesalahpahaman yang sering terjadi selama pembelajaran daring:

"Sering biasanya karena sinyal itu. Misalnya guru lagi menjelaskan pelajaran tibatiba ditengahnya putus setelah itu udah ga nyambung lagi. Maksudnya, penjelasan bapak itu sudah beda sama apa yang dijelasin sebelumnya. Aku pikir awalnya itu sinyalku yang jelek tapi pas aku melihat komentar teman-teman di Whatsapp ternyata bukan sinyalku yang jelek tapi sinyal bapaknya." (Firdaus Saragih)

Hal ini juga terdapat dalam penelitian Sadikin dan Hamidah (2020), pembelajaran daring memiliki kelemahan ketika layanan internet lemah, dan intruksi pengajar yang kurang dipahami oleh peserta didik. Tantangan lain yang dihadapi adalah kendala dalam pembiayaan pembelajaran daring. Peserta didik mengungkapkan bahwa untuk mengikuti pembelajaran daring, mereka harus mengeluarkan biaya cukup mahal untuk membeli kuota data internet. Menurut siswa, pembelajaran dalam bentuk konferensi video telah menghabiskan banyak kuota data, sementara diskusi daring melalui aplikasi pesan instan tidak membutuhkan banyak kuota.

Salah satu ciri khas dari pembelajaran daring adalah siswa harus mandiri dalam memahami materi dan mengerjakan tugas yang diberikan oleh guru. Siswa memiliki berbagai cara untuk bisa memahami materi yang telah dijelaskan oleh guru. Seperti bertanya kepada teman atau biasanya siswa sering mengirimkan materi yang telah diajarkan. Selain itu, siswa juga bertanya kepada guru yang bersangkutan. Bertanya langsung kepada guru lebih akurat daripada bertanya kepada teman sekelas. Mesin pencari Google juga sebagai salah satu wadah siswa apabila tidak mengerti materi yang diajarkan. Hal tersebut merupakan cara siswa dalam mengatasi keingintahuan mereka saat tidak mengerti materi pelajaran yang dilaksanakan secara daring.

Penelitian ini memiliki kesamaan dengan penelitian Sadikin dan Hamidah (2020) yaitu bahwa peserta didik merasa lebih nyaman dalam mengemukakan 
gagasan dan pertanyaan dalam pembelajaran daring. Pembelajaran secara daring menghilangkan rasa canggung yang pada akhirnya membuat peserta didik menjadi berani berekpresi dalam bertanya dan mengutarakan ide secara bebas.

\section{Stimulasi Alat Indra Ditafsirkan-Dievaluasi}

Pelaksanaan pembelajaran daring yang dilaksanakan siswa SMA Santa Maria Medan tidak efektif dibandingkan pembelajaran secara tatap muka. Siswa menerima materi pelajaran namun cara siswa dalam menerima pelajaran tersebut berbeda-beda. Hal ini disampaikan oleh narasumber dalam penelitian ini:

"Pendapatku pembelajaran daring ini tidak optimal ya, kayak lebih banyak kekurangan dibandingkan kelebihannya. Lebih enak tatap muka dibandingkan belajar daring ini. Pernah nih nilai olahraga saya biasanya 90 selama pembelajaran tatap muka, berbeda banget pas daring, nilaiku jadi 80 dan 87. Mungkin bisa jadi penyebabnya waktu itu disuruh bikin video praktek. Kami disuruh olahraga, di sekitar rumah saya gak ada tempat buat olahraga gitu ya jadi saya gak buat videonya. Terus juga dalam ngerjain tugas, kami lebih sering minta jawaban ke teman gitu daripada belajar, karena kami memang gak ngerti." (Aminda)

"Rumitnya pembelajaran daring itu kita harus mandiri mengerjakan tugas, sulit sekali bertanya, mencari jawaban juga harus inisiatif sendiri, lalu kuota internet harus besar kalau tidak bisa menghambat belajar nantinya, terus kami tidak bisa menikmati fasilitas sekolah padahal kami juga bayar uang sekolah." (Amanda Togatorop)

Siswa tidak memiliki minat belajar sehingga siswa lebih sering meminta jawaban kepada siswa yang berprestasi dibandingkan belajar. Selain itu, kelemahan dari sistem pembelajaran daring ini adalah kurangnya pengawasan guru dalam memantau siswanya. Sistem pembelajaran tersebut membuat siswa harus mandiri sehingga siswa melakukan segala cara untuk mendapatkan nilai bagus tanpa belajar. Hal ini dapat ditemukan juga dalam penelitian Sadikin dan Hamidah (2020) yang menemukan adanya tantangan khusus seperti lokasi peserta didik dan pengajar saat melaksanakan pembelajaran daring menyebabkan pengajar didik tidak dapat mengawasi peserta didik selama proses pembelajaran.

\section{Pengaruh Persepsi}

Sistem pembelajaran daring yang telah dilaksanakan selama ini membuat siswa berharap agar pembelajaran ini lebih baik lagi. Menurut Toha (dalam Asrori, 2020), salah satu faktor yang mempengaruhi persepsi individu adalah keinginan atau harapan dan motivasi. Tersedianya jaringan atau koneksi yang baik merupakan salah satu harapan yang diinginkan oleh siswa. Dengan tersedianya jaringan atau koneksi yang stabil, maka siswa bisa lebih memahami materi yang dijelaskan oleh guru. Penyampaian materi yang diajarkan oleh guru juga merupakan harapan siswa selama ini. Penyampaian yang diinginkan oleh siswa adalah menyampaikan materi dengan kreativitas sehingga siswa bisa lebih memahami dan semakin termotivasi untuk belajar.

"Harapannya sih, segera tatap muka saja. Karena gini, kami kan kelas tiga, kalau misalnya daring ini sampai tahun depan kayaknya masa terakhir kami itu kayak gak ada kenangannya, kayak gak berkesan dan gak ada memori bersama teman juga. 
Semenjak daring ini, harusnya kami itu udah bahas soal tapi karena Covid ini kami gak bisa bahas soal dan memang ujian nasional ditiadakan." (Aminda)

"Yang aku harapin dari pembelajaran daring ini sebagai murid ya pastinya penyampaian materi yang disampaikan dari guru bukan hanya sekedar teori aja tapi juga kreativitas perlu ditambahkan. Terus, kesepakatan keputusan antara guru, murid, dan orang tua siswa mengenai pembelajaran yang lebih memudahkan ketika pembelajaran daring tersebut." (Amanda Togatorop)

Hal ini juga ditemukan dalam penelitian Kahfi (2020) yang menemukan bahwa pengajar harus bisa memahami fasilitas pendidikan daring yang belum pernah digunakan oleh pengajar tersebut. Misalnya, guru membuat konten video kreatif sebagai bahan ajar untuk siswa sehingga siswa tertarik dan termotivasi untuk belajar serta tidak jenuh selama pembelajaran daring. Selain itu, siswa juga tidak sabar untuk segera melaksanakan pembelajaran secara tatap muka. Hal tersebut dikarenakan siswa ingin berinteraksi langsung dengan siswa lainnya. Selain keinginan atau harapan, selama pembelajaran daring siswa tidak termotivasi dalam belajar. Hal tersebut dikarenakan pembelajaran daring bersifat membebaskan siswa dalam melakukan apapun, kurangnya pengawasan dari guru merupakan salah satu alasan siswa tidak termotivasi dalam belajar. Selain itu, siswa juga semakin malas untuk belajar dan mengerjakan tugas karena cara penilaian guru yang berbeda dari pembelajaran tatap muka.

Selain itu, terdapat siswa yang merasa termotivasi selama pembelajaran daring. Sistem pembelajaran daring merupakan peluang bagi siswa tersebut untuk melaksanakan tujuannya seperti membahas soal try out dan belajar soal Seleksi Bersama Masuk Perguruan Tinggi Negeri (SBMPTN). Sistem pembelajaran daring juga memiliki keuntungan lain bagi siswa yaitu tidak menekankan status siswa sebagai pelajar SMA. Hal tersebut dikarenakan pembelajaran daring bersifat fleksibel dan bisa dilaksanakan di setiap tempat. Hal ini juga yang ditemukan dalam penelitian yang dilakukan oleh Sadikin dan Hamidah (2020) yang menemukan adanya peserta didik yang puas dengan pembelajaran daring yang fleksibel, tidak terkendala waku dan tempat. Dengan pembelajaran daring, pembelajaran dapat dilakukan dimanapun dan kapanpun tidak terikat ruang dan waktu.

Akan tetapi penelitian ini dengan penelitian yang dilakukan oleh Sadikin dan Hamidah (2020) memiliki perbedaan. Hasil penelitian Sadikin dan Hamidah (2020) yaitu bahwa peserta didik termotivasi karena sarana dan prasana yang mereka miliki cukup memadai untuk melaksanakan pembelajaran daring. Sementara itu, hasil dari penelitian ini adalah bahwa siswa memiliki sarana dan prasarana seperti Wifi dan kuota internet, namun tetap tidak termotivasi. Hal tersebut dikarenakan biaya untuk mengeluarkan kuota cukup mahal. Saat mengikuti kelas daring melalui konferensi video Zoom dapat menghabiskan kuota yang besar.

\section{Simpulan}

Persepsi bekerja berdasarkan stimulus-stimulus yang siswa alami saat melaksanakan pembelajaran daring saat Pandemi Covid-19. Berdasarkan stimulasi alat indra, siswa memahami materi yang diajarkan ketika guru dapat memberikan penjelasan materi berupa video kreatif atau beserta contoh yang relevan dikehidupan sehari-hari. Siswa tidak akan memahami materi yang diajarkan oleh guru ketika penjelasan tersebut tidak bermakna bagi siswa. Hal tersebut sering terjadi dalam 
pelaksanaan pembelajaran daring, siswa sering tidak mengerjakan tugas yang telah diberikan guru karena tidak mengingat bahwa terdapat tugas yang harus dikerjakan.

Pada tahap stimulus alat indra yang diatur, siswa mempersepsikan suatu pesan yang dalam kenyataan tidak lengkap menjadi suatu pesan yang lengkap. Pesan yang tidak lengkap tersebut terjadi ketika adanya kesalahpahaman dalam berkomunikasi atau miscommunication. Penyebab tersebut dikarenakan jaringan internet siswa lemah atau sebaliknya. Materi tersebut bisa terdengar ambigu bagi siswa sehingga siswa harus belajar mandiri untuk mengerti dan memahami penjelasan guru. Pada tahap stimulasi alat indra ditafsirkan-dievaluasi, pelaksanaan pembelajaran daring yang dilaksanakan siswa SMA tidak efektif dibandingkan pembelajaran secara tatap muka.

Faktor internal yang mempengaruhi persepsi siswa yaitu harapan dan motivasi. Tersedianya jaringan yang baik atau koneksi yang stabil merupakan salah satu harapan yang diinginkan oleh siswa. Selama pembelajaran daring siswa tidak termotivasi dalam belajar karena cara penilaian guru yang berbeda dari pembelajaran tatap muka. Kendati demikian, terdapat siswa yang termotivasi selama pembelajaran daring. Hal tersebut dikarenakan pembelajaran daring bersifat fleksibel dan bisa dilaksanakan dimanapun. Faktor eksternal yang mempengaruhi persepsi siswa SMA adalah sistem pembelajaran daring tidak berbeda dengan tatap muka dalam hal pekerjaan rumah. Siswa tetap memiliki kewajiban untuk mengerjakan tugas yang diberikan oleh guru.

\section{Ucapan Terima Kasih}

Penulis mengucapkan terima kasih kepada seluruh pihak yang telah mendukung dan membantu penulis selama proses penelitian berlangsung sampai dengan terbitnya jurnal penelitian ini.

\section{Daftar Pustaka}

Asrori. (2020). Psikologi Pendidikan Pendidikan Multidisipliner. Banyumas: Penerbit CV Pena Persada.

DeVito, Joseph A. (2011). Komunikasi AntarManusia. Tangerang: Karisma Publishing Group.

Kahfi, Ashabul. (2020). Tantangan dan Harapan Pembelajaran Jarak Jauh di Masa Pandemi Covid-19. Dirasah (Jurnal Pemikiran \&Pendidikan Dasar Islam), 3(2), 137-154.

Mulyana, Mumuh et al. (2020). Persepsi Mahasiswa Atas Penggunaan Aplikasi Perkuliahan Daring Saat Wabah Covid-19. Jurnal Analisis Sistem Pendidikan Tinggi Indonesia), 4(1).

Sadikin, A., \& Hamidah, A. (2020). Pembelajaran Daring di Tengah Wabah Covid19: (Online Learning in the Middle of the Covid-19 Pandemic). BIODIK, 6(2), 214-224. https://doi.org/10.22437/bio.v6i2.9759

Sugiyono. (2015). Metode Penelitian Pendidikan (Pendekatan Kuantitatif, Kualitatif, dan $R \& D$. Bandung: Penerbit Alfabet.

Wardani, DN, Toenlioe, AJE, Wedi A. (2018). Daya Tarik Pembelajaran di Era 21 dengan Blended Learning. Jurnal Kajian Teknologi Pendidikan. 1(1), 13-8).

Wood, J. T. (2011). Communication Mosaics an Introduction to the Field of Communication Sixth Edition. Boston, MA: Wadsworth Cengage Learning. 